\title{
Developing an Android-based Screen Lock Application for Arabic Vocabulary Enrichment of the Tenth Graders at the Madrasah Aliyah
}

\section{Achmad Tohe, Muhammad Aliyudin Al-Ayubi, and Ali Maksum}

Arabic Department, Faculty of Letters, State University of Malang

\section{Abstract}

This research aims at developing an Android-based screen lock application for Arabic vocabulary enrichment of the Tenth Grade Students at the Madrasah Aliyah. The research design used is the research and development model proposed by Borg \& Gall, with some modification, according to the research needs. The Data are gathered through scoring sheets and then analyzed using descriptive and percentage techniques. The end result of the research is an Android-based screen lock application

Corresponding Author:

Achmad Tohe

achmad.tohe.fs@um.ac.id

Received: 23 January 2019 Accepted: 26 February 2019 Published: 17 March 2019

Publishing services provided by Knowledge E

(c) et al. This article is distributed under the terms of the

Commons Attribution License, which permits unrestricted use and redistribution provided that the original author and source are credited.

Selection and Peer-review under the responsibility of the International Seminar on Language, Education, and Culture Conference Committee. that consists of seventy sets of Arabic vocabulary, containing three hundred Arabic words. These vocabulary items are presented randomly on the handphone's screen as a set of questions whose correct answers will allow students to have access to their phones. The results of the research demonstrate that according to the expert and field test the application is valid, with each of the content and appearance experts scored $82 \%$, and both teacher and students at the school scored $95 \%$ and $81 \%$, respectively.

Keywords: Android, screen lock, application, Arabic vocabulary, tenth grade, Madrasah Aliyah

\section{Introduction}

Having a wide range of vocabularies of a language, including Arabic, is required for one to be able to communicate well (Harmer, 2001; Effendy, 2012). The same applies to the students of Arabic in Indonesia, at all levels of education, who study and learn it as a foreign language. It is only with a sufficient amount of vocabularies that students of Arabic will be able to convey their ideas in that language onto others or, at the very least, to understand other people's ideas expressed in both spoken and written forms (Wilkins, 1987).

Regardless of the fundamental role that the vocabulary plays in terms of one's fluency with regard to a certain (foreign) language, it has been well known that students have commonly struggled with vocabulary-related problems. Research shows that one of the 
main reasons student having difficulty in grasping the learning material of a foreign language, especially Arabic, is partly due to the relative dearth of their vocabulary reservoir (Hardiansyah, 2015). The same reason, accordingly, leads to the relatively low grades that the students gain with regard to foreign language learning (Alifia 2015). For any language learning to be successful, such vocabulary-related problems require urgent attention to solve.

A practical solution, among many other, that can be proposed is developing learning media that takes advantage of the advances in information technology, such as handphones. Learners today, who have been dubbed "digital natives" (Prensky, 2001) or "millennial learners" (Howe and Strauss, 2000), seems to have been accustomed to mobile learning through, inter alia, their phones that are always connected to the internet. Wherever they go, inside or outside the classroom, this younger generation of students have always had their phones in their hands. It is, therefore, appropriate to develop a handphone application that will help students increase their vocabularies of Arabic and ultimately solve their vocabulary-related problems for better learning.

Both educational practitioners and experts have acknowledged the importance of learning media to create an effective and efficient learning environment (Rusman, 2013). These learning media must be selected carefully in order to enable students to learn and gain certain skills, including in Arabic learning (Asrori and Ahsanuddin (2015). There are different kinds of learning media, including projectors, audios, videos, films, and other multimedia devices (Susilana and Riana, 2009).

One of such media that can be integrated into learning is Android-based programs, that is, a linux-based operation applied to cellular phones. Some advantages of this program is that it is an open source, multi-tasking, free platform, easily stored, and cost efficient (Waloeyo, 2012). There are different types of screen lock model, such as swipe, PIN, password, and pattern (Wachsman, 2014). In the case of this study, the application that it will develop is designed to be operated through handphones' screen lock by displaying a set of questions using Arabic vocabularies. Students will have to answer the questions correctly in order to have access to their handphones.

\section{Method}

The research and development design used in this study is one offered by Borg and Gall, with some modification, according to the needs. As such, this includes: (1) needs analysis, (2) product design, (3) expert examinations, (4) product's first revision, (5) a limited field test, (6) final revision, and (7) dissemination and implementation. The research 
was conducted at the Public Madrasah Aliyah I Malang, with the subject consisting of one learning material expert, one learning media expert, one Arabic teacher, and twenty-two tenth graders learning Arabic at social sciences concentration of the school. The research instruments used are validation sheets, which contain scoring items in terms of the applicability of the Arabic vocabulary screen lock developed, to assess: material design and organization, content validity, and application's appearance. The same validation sheets are to gather qualitative data with regard to suggestions and comments for further improvement, as well as quantitative data in the form of scores that measure the validity both of the application's content and format.

\section{Result and Discussion}

\subsection{Needs analysis}

According to the Curriculum 2013, there are six themes offered in Arabic learning for the tenth grade, including al-bayanat al-shakshiyyah (personal information), al-marafiq al-ammah fi al-madrasah (public facilities at school), al-hayah fi al-usrah wa fi sakan althullab (life at home and at the dormitory), hiwayat al-thullab wa al-ma'rad (students' hobbies and affairs), and al-mihnah wa al-nizam (profession and regulation). In this respect, students are expected to acquire two hundred and fifty vocabularies.

Based on the observation, the textbook used in the tenth grade at the Madrasah Aliyah is published by the Ministry of Religious Affairs of the Republic of Indonesia, in the year 2015. The book covers all the six themes mentioned above and is used for the whole year, in two semesters. The most frequently used vocabularies therein are nouns and verbs. The teaching methods commonly used in the vocabulary learning are providing synonyms, antonyms, clusters of words, and putting them in context.

\subsection{Product design}

\subsubsection{Software and hardware}

This research decided to use the Android Studio program version 2.3, for it has all the components needed including programing language (Java), lay-outing (xml), and database (SQLite). The production process used hardware with certain specification: Intel processor Core i7, 16 GB of RAM, on a computer set with Linux Ubuntu v16.0 operation. 


\subsubsection{Program plot}

This screen lock application contains a set of multiple-choice questions on certain Arabic words displayed on the handphone's screen. Questions will come up randomly. Students will have to answer a question correctly before they can access their phones. If their answer was wrong, the next questions will come up, alternately and randomly, until the answer given is correct. The following is an illustration of the plot.

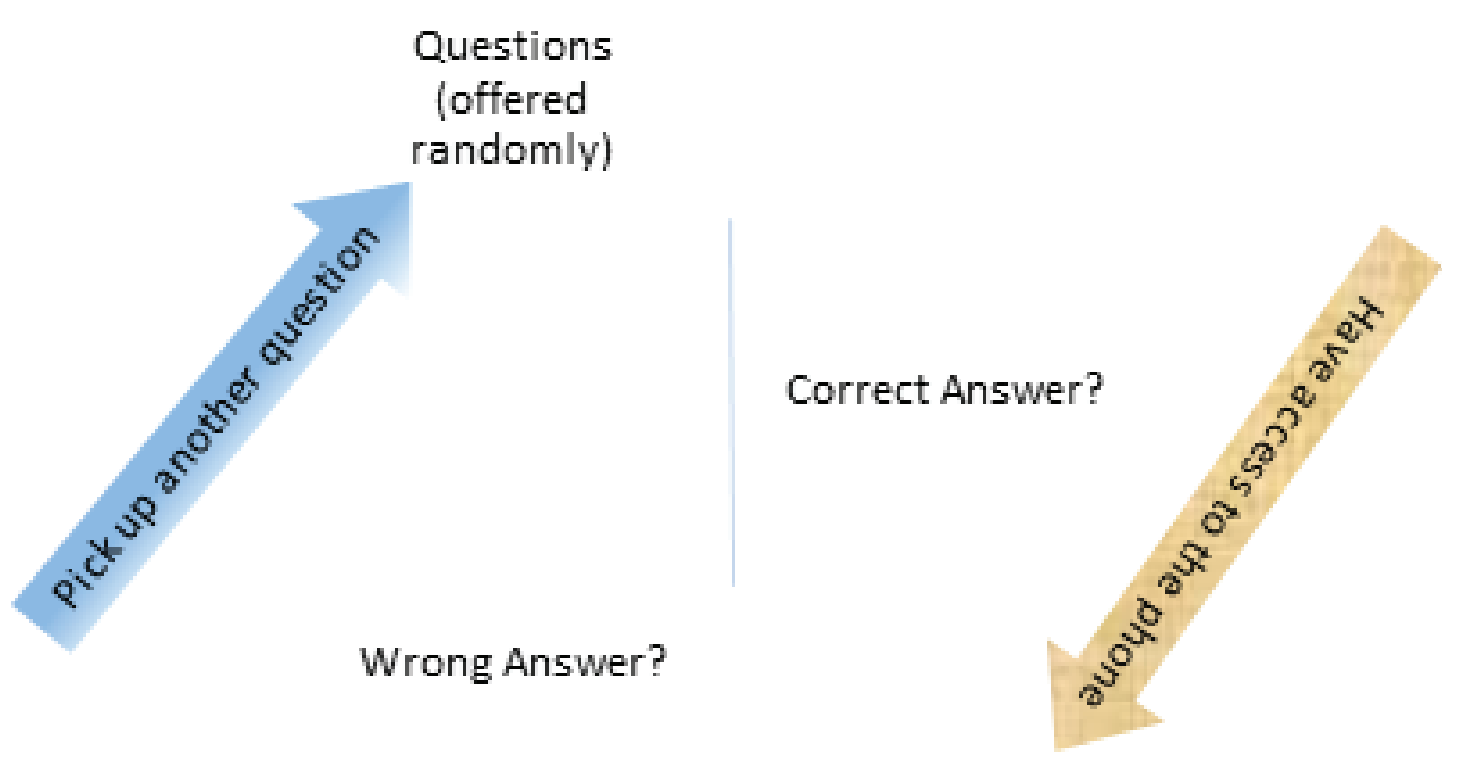

Home Screen

Figure 1: Program Plot.

\subsubsection{Lay-outing}

The application lay-outing accomplished by using Android Studio Program version 2.3, with an xml format, composed of questions, answers, and announcement.

\subsubsection{Database}

The selected vocabularies culled from the Arabic textbook for the tenth grade of the Madrasah Aliyah are registered and input, to be connected with the application using SQLite database. 


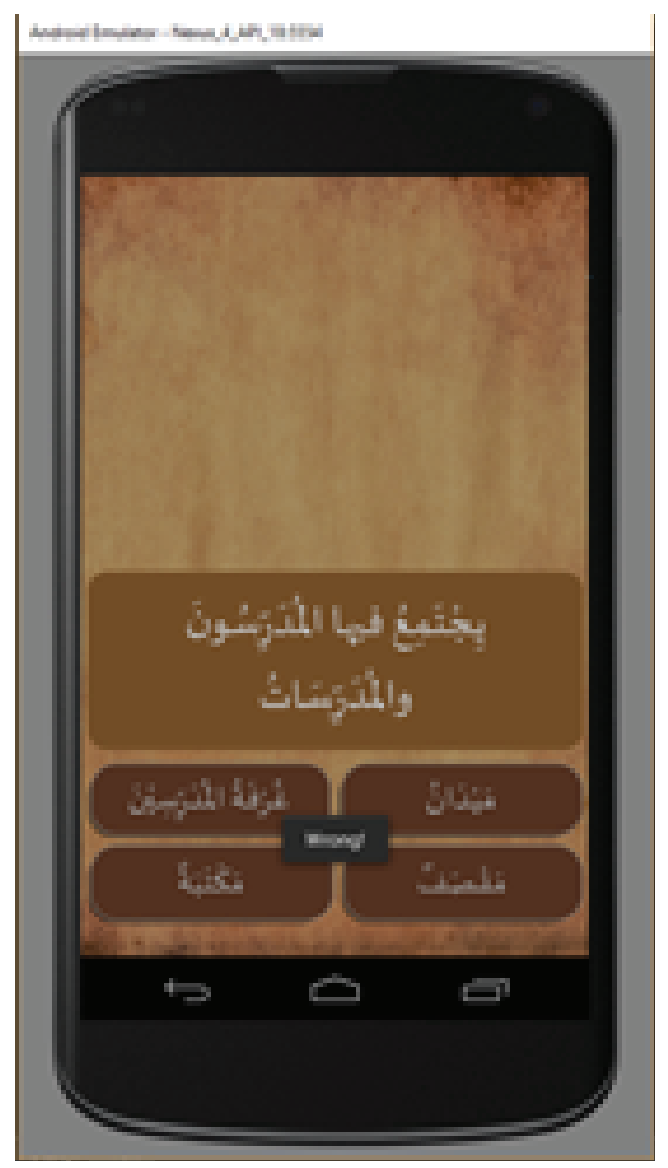

Figure 2: Application Layout.

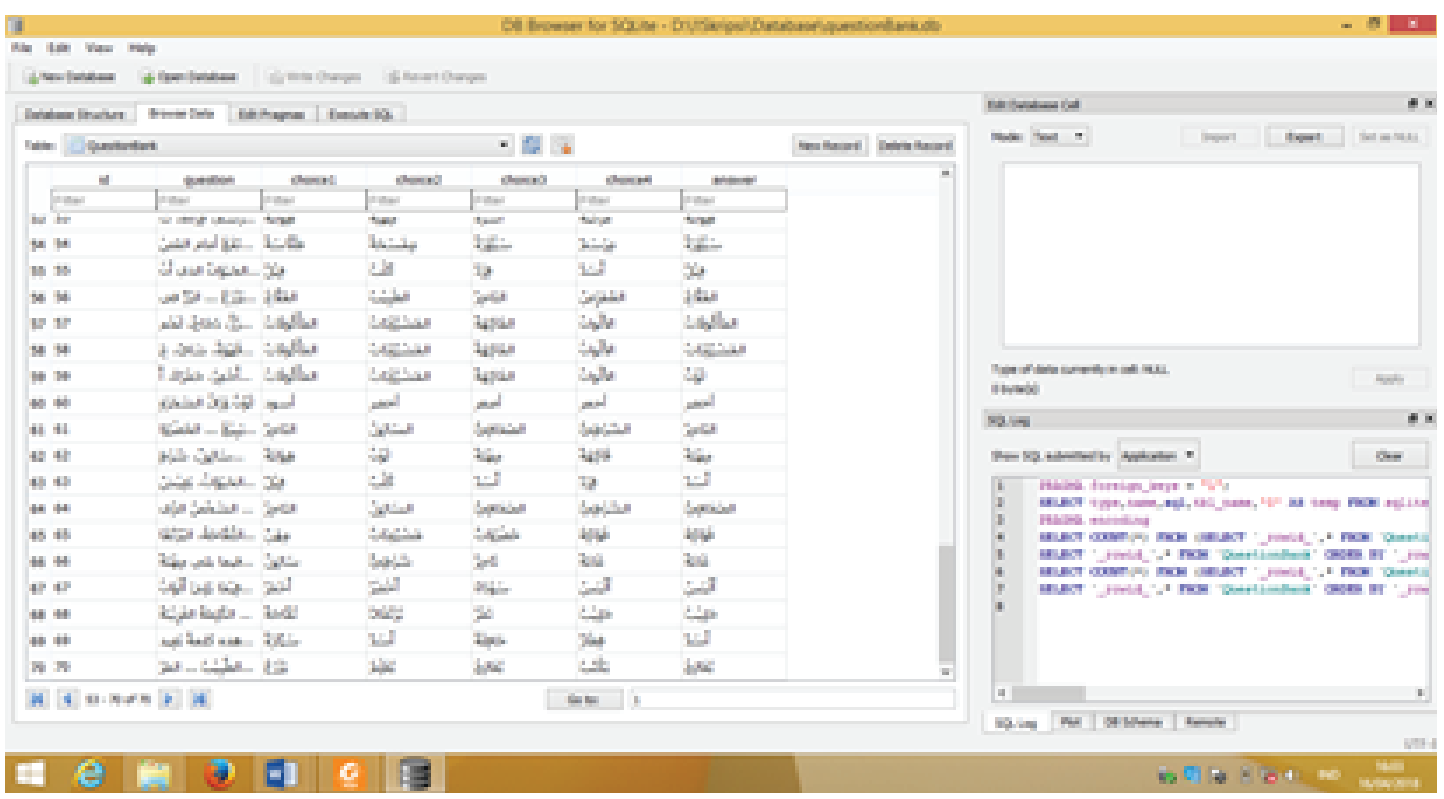

Figure 3: SQLite Database. 


\subsubsection{Experts' examination and validation}

The examination and validation involved two experts: one of the content, and another of the media appearance. Acting as a content expert was Prof. Muhaiban, a faculty member of the Arabic Department, Faculty of Letters, State University of Malang. The examination of content was conducted on March 29, 2018. Wahib Dariyadi, another faculty member of the same department and the owner of the software development company (PT. Optima Media), examined the media appearance on March 29, 2018.

The results of the examination show that the developed application is valid, both in terms of content (82\%) and appearance (82\%). In addition to scoring the validation items, the two experts also commented upon the application prototype for revision and further development. Of such comments include the need to correct some typos, instructions, and icons, and to Arabicize the whole instructions in the application, some of which was given in English.

\subsubsection{Field test and validation}

The field test was undertaken at the Public Madrasah Aliyah I in Malang, commonly known as "MAN Gondanglegi." Mrs. Muyassaroh, the Arabic teacher at the school, supervised the field test, and twenty-two tenth graders were representing their cohorts to participate in it. The results of the field test demonstrated that the application developed is valid and applicable for Arabic vocabulary learning (the teacher gave a score of $95 \%$, and the participating students $81 \%$ ).

\subsubsection{Product revision}

While the product, in general, is regarded as valid and applicable for learning, it is however in need for some revision, as recommended by the two experts of content and appearance, as well as the Arabic teacher at the school. The revision can be described as the following.

\section{Conclusion}

The developed screen lock application is Android-based, formatted as .apk, and has a 4 $\mathrm{Mb}$ file. The application will appear on the handphone's screen anytime it is turned on. But the handphone will be accessible only after students have answered correctly the 


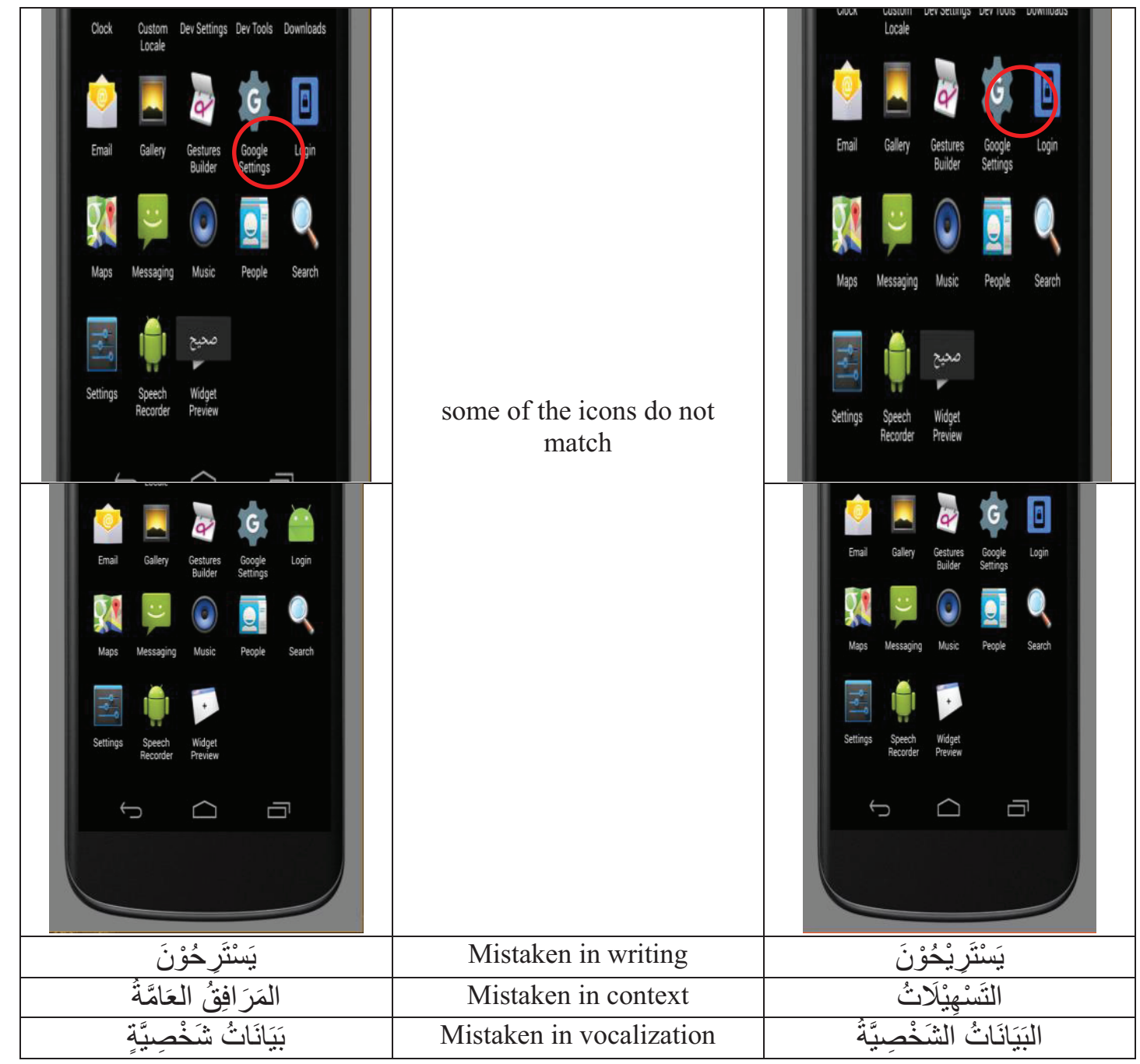

Figure 4: Product Revision.

questions given on the screen. The application contains seventy sets of multiple choice questions consisting of vocabularies found in the tenth-grade textbook of the Madrasah, as mandated by the Curriculum 2013, which cover six themes including al-bayanat alshakshiyyah (personal information), al-marafiq al-'ammah fi al-madrasah (public facilities at school), al-hayah fi al-usrah wa fi sakan al-thullab (life at home and at the dormitory), hiwayat al-thullab wa al-ma'rad (students' hobbies and affairs), and al-mihnah wa al-nizam (profession and regulation). The available questions, offered randomly, address different topics, namely asking for synonyms, antonyms, plural forms, singular forms, clusters of words, and putting words in context. The amount of vocabularies provided is three-hundred words, including both nouns and verbs.

The results of expert tests, both of content and appearance, show that the application is valid (82\%). Likewise, the field tests by both teacher and students suggest that it is valid and applicable, by $95 \%$ and $81 \%$ respectively. Nonetheless, revision and further 
development of the product was conducted based on the comments provided by the two experts and the teacher at the school. Such revision included the correction of used words and vocalization, of the answers given to some questions, and the Arabicization the whole instruction and announcement.

In the future, it is recommended that both teachers and tenth graders of the Madrasah Aliyah will use the application to support their learning of the Arabic vocabularies. To do so, they will need to install it onto their handphones. While it is initially meant to be used in high school level of Arabic learning, any students of Arabic can also take advantage of the developed application. As it is also recommendable for anyone with adequate expertise, in both content and technology, to improve the application by adding audio, video, and other vocabularies. Given its potentiality, it is also worth considering the use the same application for subjects other than Arabic or any other language learning.

\section{References}

[1] Alifia, A. 2015. Pengembangan Bahan Ajar Bahasa Arab Berbasis Web Untuk Siswa Kelas X SMAN Rejotangan Tulungagung. Skripsi tidak diterbitkan. Fakultas Sastra, UM.

[2] Asrori, I., \& Moh. Ahsanuddin. 2015. Media Pembelajaran Bahasa Arab. Malang: CV. Bintang Sejahtera.

[3] Effendy, A.F. 2012. Metodologi Pengajaran Bahasa Arab. Malang: Miskyat.

[4] Hadiansyah, H. 2015. Pengembangan Media Pembelajaran Bahasa Arab Berbasis Android Untuk Siswa Kelas X Madrasah Aliyah. Skripsi tidak diterbitkan. Fakultas Sastra, UM.

[5] Harmer, J. 2001. The Practice of English Language Teaching. London: Longman.

[6] Howe, N. \& William Strauss. 2000. Millennial Rising: the Next Great Generation. New York: Vintage Books.

[7] Prensky, M. 2001. Digital Natives, Digital Immigrants Part 1. The Horizon, Vol. 9 Issue: 5, pp.1-6, https://doi.org/10.1108/10748120110424816.

[8] Rusman. 2013. Belajar dan Pembelajaran Berbasis Komputer. Bandung: Alfabeta.

[9] Susilana, R., \& Riana, C. 2009. Media Pembelajaran: Hakikat Pengembangan, Pemanfaatan, dan Penilaian. Bandung: CV. Wacana Prima.

[10] UNESCO, (2012). Mobile Learning for Teachers in Africa and the Middle East. UNESCO Working Paper Series on Mobile Learning. Paris, France: United Nations Educational, Scientific and Cultural Organization. 
[11] Wachsman, D. 2014. Android Screenlock, (online), http://www.coolindictionary.com/ submission/13578/Lock+screen.com, accessed Mei 10, 2018.

[12] Waloeyo, Y. J. 2010. Google Android Sistem Operasi Ponsel Masa Depan. Yogyakarta: Andi dan Elcom.

[13] Wilkins, D. 1972. Linguistic and Language Teaching. Australia: Edward Arnold. 